NBER WORKING PAPER SERIES

\title{
TESTING THE RATIONALITY OF
}

STATE REVENUE FORECASTS

\author{
Daniel R. Feenberg \\ William Gentry \\ David Gilroy \\ Harvey S. Rosen
}

Working Paper No. 2628

\author{
NATIONAL BUREAU OF ECONOMIC RESEARCH \\ 1050 Massachusetts Avenue \\ Cambridge, MA 02138 \\ June 1988
}

This research was supported by a grant from the olin Foundation to Princeton University, and by the state and Local Government Finance Project of the National Bureau of Economic Research. We are grateful to Dan Breen, Clifford Goldman, James Hines, Richard Keevey, Whitney Newey, Kenneth West and James wooster for useful conversations. This research is part of NBER's research program in Taxation. Any opinions expressed are those of the authors and not those of the National Bureau of Economic Research. 
NBER Working Paper \#2628

June 1988

TESTING THE RATIONALITY OF STATE REVENUE FORECASTS

\section{ABSTRACT}

Ir recent moritis, the goverriors of several states have suffered maior political embarrassments because actual revenues fell substantially short of the predictions in their respective budgets. Such episodes forus attention on the question of whether states do a "good" job of forecasting revenues. In modern ecoromics, forecasts are evaluated on the basis of whether or not they are "rational" -.... do the forecasts optimally incorporate all information that is available at the time they are made? This paper develops a method for testing the rationality of state reverue forecasts, and applies it to the analysis of data from New Jersey, Massachusetts, and Maryland. one of our mair firidinge is that in all three states, the forecasts of owr revenues are systematically biased dowriward.

\author{
Daniel R. Feenberg \\ N.B.E.R. \\ 1050 Massachusetts Avenue \\ Cambridge, MA 02138 \\ David Gilroy \\ Department of Economics \\ Princeton University \\ Princeton, NJ 08544
}

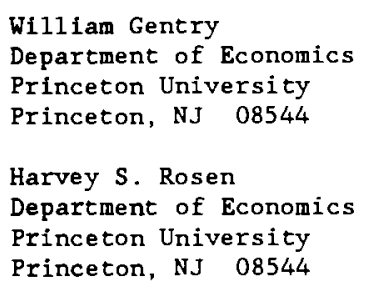

William Gentry

Department of Economics

Princeton University

0854

Department of Economics

Princeton, NJ 08544 


\section{Introduction}

In 1985 , the 50 states raised $\$ 349$ billion in revenues from their own sources, and received $\$ 84$ billion in grants from the federal government. (U.S. Bureau of the Census [1987, p. 266].) State governments are clearly important players in the U.S. system of public finance, and the efficiency with which they conduct the ir financla 1 affairs has an important impact on consumer welfare. One important determinant of a state's ability to conduct reasonable fiscal policies is the quality of its revenue forecasts. Sensible deliberations about expenditures cannot be made in the absence of "good" forecasts. Indeed, in the presence of constitutional or statutory provisions for balanced budgets, unanticipated changes in revenues can wreak havoc not only on proposals that are scheduled for funding, but on plans that have a lready been put into effect as well.

In recent months, two powerful governors, Michael Dukak is of Massachusetts and Mario Cuomo of New York, have suffered major political embarrassments because actual revenues fell substantially short of the predictions in their respective states. Such episodes focus attention on the question of whether states do a "good" job of forecasting revenues. In modern economics, forecasts are evaluated on the basis of whether or not they are "rational"--do the forecasts optimally incorporate all information that is avallable at the time they are made? Although there is a large literature on state revenue forecasting methods, that 1 iterature focuses mostiy on state budgetary institutions. Forecasts themselves are evaluated only in an informa 1 fashion. 1 Although the theory and econometric methods of rational expectations have been used to evaluate forecasts made by households and businesses, 2 these powerful tools have not been applied to state government 
forecasts. This paper brings these methods to bear on the problem of state revenue forecasting, and as an example, applies them to the analys is of data from New Jersey, Massachusetts, and Maryland. The results cast 1 ight not only on the question of rationality per se, but on issues such as the impact of political factors on forecasts.

Section II presents the conceptual framework for testing rational expectations. The relevant institutional issues and data are described in Section III. Estimation problems and results are discussed in Section IV. We find that in a 11 three states forecasts of own revenues are systematically biased downward. Section $V$ concludes with a summary and suggestions for future research.

\section{Basic Concepts}

State revenue forecasters operate in an environment characterized by great uncertainty. Future revenues generated by a given revenue structure depend on future values of varlables like employment, population, and nominal income, none of which is easy to predict. Additional uncertainty is created by the fact that the state tax structure itself may be changed in the future. Such changes depend in part on the political climate in the state, another thing that is hard to predict. To make matters even more complicated, state revenues may depend upon difficult to forecast actions taken by the federal government. For example, in 1986, the federal government announced that after that year, state sales taxes would no longer be deductible on federal tax returns. As a consequence, many taxpayers moved up their purchases of durables to 1986, creating an unanticipated increase in sales tax revenues that year.

Operating in such an environment, forecasters cannot be expected to 
obtain precisely correct answers. Rather, the most one can ask is that forecasters do as well as possible given the avallable information at the time the forecast is made. To formalize this notion, let $R_{t}$ be the actual percent change in nominal revenues in period $t$, and $R_{t-f}^{e}$ be the forecast of $R_{t}$ made $f$ periods ago. $3 I_{t-f}$ is the set of information avallable when the forecast is made. By definition, the conditiona 1 expectation of the forecast error, $v_{t-f}$, given this information set, is

$$
\text { (2.1) } v_{t-f}=E\left[\left(R_{t}-R_{t-f}^{e}\right) / I_{t-f}\right]
$$

Following Brown and Maital [1981], note that (2.1) implies the following regression equation:

$$
\text { (2.2) }\left(R_{t}-R_{t-f}^{e}\right)=v_{t-f}\left(I_{t-f}\right)+u_{t} \text {. }
$$

where $E\left[u_{t} \mid I_{t-f}\right]=0$.

The forecast $R_{t-f}^{e}$ is said to be strongly rational if $R_{t-f}^{e}=E\left[R_{t} \mid I_{t-f}\right]$. From equation (2.2), this implies that $v_{t-f}\left(I_{t-f}\right)$ is zero. Hence, suppose we estimate a regression of $\left(R_{t}-R_{t-f}^{e}\right)$ on $I_{t-f}$. If the variables included in $I_{t-f}$ are statisticaliy significant, then we can reject the hypothes is of strong rationality. Intuitively, if predictions are strongly rational, then $R_{t-f}^{e}$ should incorporate all relevant information available at the time the forecast is made. Therefore, the forecast error $\left(R_{t}-R_{t-f}^{e}\right)$ should be uncorrelated with any of this information.

Suppose now that only a subset of $I_{t-f}$ is utilized in making the prediction. If this subset is used efficiently, then the forecast is said to be weakly rational. That is, even if all information is not fully utilized, the forecaster gets the correct answer on average. 
Like strong rationality, weak rationality has a simple interpretation in a regression framework. Suppose we estimate

$$
\text { (2.3) } R_{t}=a_{0}+\alpha_{1} R_{t-f}^{e}+u_{t} \text {. }
$$

If $R_{t-f}^{e}$ is weakly rational, then $\alpha_{0}=0$ and $\alpha_{1}=1$. Hence, a test of weak rationality requires only that we estimate (2.3) and use appropriate statistical methods to test that joint hypothesis.

There are conflicting views with respect to whether revenue predictions are unblased, and if not, whether revenues are over or underpredicted. Klay [1983, p. 308] argues that the forecasts are systematically too low:

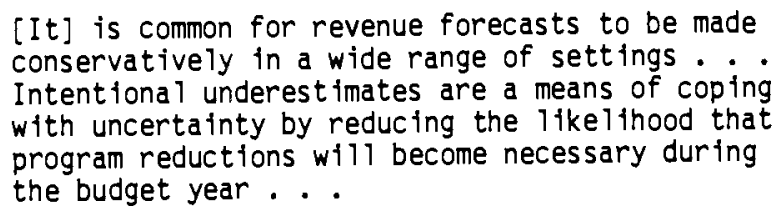

Indeed, if a surplus "unexpectedly" surfaces during the budget year, this might enhance the popularity of the administration. Another possible motivation for underpredicting revenues is to conceal from legislators and special interest groups the resources that are avallable to them. Glovinazzo [1971, p. 103] quotes former New Jersey Governor Driscoll as saying, "What the Legis lature can't find, It can't spend."

On the other hand, there are also arguments that forecasters have incentives to overestimate revenues. High revenue forecasts might help support efforts to borrow money to pay for operating expenses. One revenue estimator interviewed by Giovinazzo [1971, p. 19] indicated that he sometimes faced political pressures to overestimate revenues: ". . occasionally friendly persuasion and reasoned discussion [were] brought to bear on $\mathrm{h} / \mathrm{m}$ with the aim of convincing him to increase some of his estimates." 
It is reasonable to ask whether over- or underpredicting revenues year after year is a viable strategy for fooling people. One would expect that eventually the forecasts would lose credibility. This point is especially telling in states whose legislatures have their own revenue forecasting organizations. (The legislatures of New Jersey and Maryland have such organizations; Massachusetts does not.) Indeed, it could also be argued that like the ir counterparts in the private sector, public sector officials have incentives to forecast rationally. The present and former state budget officials with whom we spoke claimed that they did their best to be on target. Interestingly, they stated that unexpected surpluses are just about as bad as deficits from their point of view. When there is an unexpected surplus, much of the extra revenue goes to localities. While the localities are happy to receive the new money, they are irked that they have to re-do their planning, and resent the fact that they were not given correct figures at the outset. Budget officials also emphasized the fact that the newspapers point out forecast errors very aggressively, whether they are negative or positive. This observation is consistent with press reports that in 1988 , Governor Cuomo was ". . . annoyed that his budget aids had embarrassed him by underestimating revenue... In each of the three previous years, [and] ordered them this year not to be so conservative." 4 Taken together, these considerations suggest that forecasters have incentives to be rational in the technical sense defined above.

In short, there appears to be substantial disagreement regarding the likely outcome of estimating equation (2.3). Resolution of this disagreement requires analysis of the data. 


\section{Institutional 8ackground and Data}

\section{A. The 8udgetary Process}

New Jersey. The last week of every January the Governor of New Jersey submits to the legislature a budget statement that includes forecasts of revenues and expenditures. 5 The forecast for each item is made over two time horizons. The first, which we call the short forecast, is for the fiscal year that began the previous July 1 . The second, which we call the long forecast, is for the fiscal year beginning the subsequent July 1 . Hence, the short forecast presented in January 1988 covers the period July 1, 1987 to June 30, 1988; the long forecast contained in that message is for July 1, 1988 to June $30,1989$.

In most states, forecasts are made by a budget division with in the executive branch (Hyde and Jarock $1[1983$, p. 266]). The final responsibility lies with the governor, who reviews the forecasts, and can modify them before presentation. New Jersey is typical in these respects. Lega 1 responsibility for revenue estimation resides with the Governor and the Director of Budget and Accounting. However, the forecasts are developed in consultation with a number of offices in the executive branch, particularly the varfous tax bureaus.

The forecasting process begins in the October preceding the budget address, and a set of figures is produced by November. However, these figures are usually revised once or twice before the budget message goes to press in January.

Revenue forecasting methods differ widely across the states. Some states rely on econometric models, others on much more informal methods. In the early 1970s Glovinazzo [1971, p. 27] noted that in New Jersey "formalized, systematic techniques are seldom, if ever, used." Rather than 
using econometric models, forecasters used a "Judgmenta 1 approach"--they informally analyzed past trends in different revenue sources, and relied heavily on the expertise of members of the various tax bureaus. Our conversations with current and recent budget officials indicated that this is still pretty much the case. These officials indicated that attempts at econometric modelling generally led to disappointing results, and that it was better to rely on the advice of "oid hands" who had a good sense of what was really going on in the state. Revenue forecasts are made entirely in-house; there is no contracting to outside consultants.

Massachusetts. The Massachusetts institutions are very simflar to those of New Jersey. Revenue estimates are prepared each November, and forwarded to the Governor, who presents them during the last week of the following January. These estimates are prepared by the Bureau of Administration and Finance (BA\&F). Forma 1 econometric modelling plays a somewhat greater role than it does in New Jersey. Specifically, BA\&F receives econometric forecasts for Massachusetts generated by a consulting firm (Data Resources, Inc.), and then plugs these forecasts into a micro simulation model based on Massachusetts tax returns. However, all forecasts are subject to the judgment of "old hands," and some revenue sources are forecast without any formal modelling at a11. Corporate income taxes were offered as an example where familiarity with individual cases was sufficlently important that "judgment forecasts" were used to the exclusion of statistical forecasts.

Maryland. Estimates of state revenues in Maryland are developed through a process that is similar to the processes of New Jersey and Massachusetts. Revenue forecasting is carried out by the Bureau of Revenue Estimates (BRE) under the superviston of the State Comptroller. Treasurer, and Secretary of Budget and Fiscal Planning. The Governor receives the estimates in 
mid-December and incorporates them into his budget message which is presented to the state legislature in mid-January.

The use of econometric forecasting techniques appears to be more prevalent in Maryland than in either New Jersey or Massachusetts. Regression models have been utilized in forecasting state revenues in Maryland since the early 1970s. The models tend to be quite simple--generally there are fewer than three explanatory variables for each revenue source, and estimation is by ordinary least squares. While revenue forecasting models are developed entirely in-house, BRE officials depend significantly on outside econometric forecasting services for the information on which the models are based. Such services provide forecasts of various explanatory variables such as state personal income. As of 1987 , econometric methods were applied to revenue sources that comprised $87.5 \%$ of Maryland tax revenues.

of course, the unvarnished regression output is not included in the governor's message--quite a few modifications are made. Nevertheless, it will be of some interest to see whether the heavier reliance on econometrics leads to more accurate iorecasts.

\section{B. Data}

New Jersey. The budgetary data are from the budget messages of February 1948 through January 1987. Although budget documents were avallable back to the 1930s, there appears to have been a change in accounting conventions after World War II that made it difficult to construct a coherent time series.

For each revenue source, the budget contains the actual value for the fiscal year that ended the previous June 30 , as well as the short and long forecasts for each revenue source. The actual percent changes correspond to the $R_{t}$ 's of the previous section, and the forecasts are the $R_{t}^{e}$ 's.

State revenues are disaggregated very finely. In 1985 there were over 
170 revenue sources, which included items such as hunters' 1icense fees and shell fisheries leases. For many of these individual items, the time series are not very long--particular taxes and 1icense fees come and go.6 for this reason and for purposes of simplicity, we aggregated a 11 revenues into two categorles, revenues froii own sources and revenues in the form of grants from the federal government. The distinction between own source revenues and grants has played an important role in both theoretical and econometric analys is of state and local government fiscal decisions (see Inman [1979]); it seems worthwhile to investigate whether the expectational mechanisms for the two revenue sources differ. As in most states, federal grants have played a very important role in the New Jersey budget. In 1986, grants were 25 percent of own source revenues; the ratio has been as $h i g h$ as 40 percent. In addition to budgetary data, execution of the strong tests requires the variables in the information set. As usual in studies of this $k$ ind, it is not quite clear how to answer the question, "What did they know and when did they know 1t?" For the "what" part of the question, we assume that information on the percent changes in the following economic and demographic variables is relevant for predicting future revenues: nominal personal income (INC), population (POP), consumer price index (CPI), non-agricultural employment (EMP), and the lagged value of revenue itse if $\left(R_{t-f-1}\right)$. Except for lagged revenue, each variable is avallable on a calendar year bas is. 7 This leads to a complication in answering the "when" part of the question. Given that the forecasts are made before the calendar year is entirely over, it is not clear whether variables dated that year should be included in the information set. On one hand, it could be argued that even though the officlal estimates for the year are not out by December, officials can monitor things closely enough to have a pretty good idea of what the values 
are. However, one could Just as well argue that the actual values for these variables may be quite different from the officials' perceptions. Our conversations with budget officials indicated that except for income, it is reasonable to treat the variables as "known" by the time the forecasts are made. On the other hand, income data are available only with a lag; hence, only the lagged percentage change in income is assumed to be in the information set.

As noted in Section II, revenue forecasts must take into account possible changes in tax structure that will be enacted by the legislature and signed by the governor. Hence, revenue forecasters must make political as well as economic forecasts. Variables that might help predict the political climate should therefore be included in the information set. For these purposes, we define the following dichotomous variables:

GOVAGR = 1 if the party of the governor is the same as the majority in the legislature, and zero otherwise. (If the two houses are split, GOVAGR $=0.5$.)

REPUB = 1 if the governor is a Republican, and zero otherwise

ELECTYR = 1 if the message is presented in an election year, and zero otherwise

FIRSTYR $=1$ if the message is presented in the first year of a governor's administration, and zero otherwise.

Some summary statistics regarding forecast accuracy for New Jersey are presented in Table 1a. The first row shows the average percent change in each revenue source during the sample period. Own revenues grew at an annual rate of about 10 percent during our period, and grants from the federal government at about 14 percent. The relatively large standard deviations suggest that this growth was not smooth, however. The next three rows show several ways of summarizing the forecast errors for the various revenue sources. Row 2 has the mean forecast error. These figures suggest that there was a 
conservative blas in the forecasts. For example, on average, the actual year to year percent increase in own revenues exceeded the forecast increase by 2.92 percentage points; for grants the forecast averaged 2.19 percentage points below actual growth. Of course, these figures are only suggestive; correct testing for the presence of bias requires the methods outlined in the previous section. The third row of Table la shows the mean of the absolute value of the difference between the actual percentage change and the predicted percentage change, and row 4 shows the root mean squared error. The general impression conveyed by the table is that own revenues are predicted better than grants.

Another interesting question about the forecasts is whether they have been improving over time. To investigate this issue, we estimated a series of regressions of the form $\mid R_{t}-R_{t-f^{\prime}}^{e}=\gamma_{0}+\gamma_{1} t$. An estimate of $\gamma_{1}<0$ would suggest that the absolute value of the forecast error has been falling, mutat is mutandis. The results, reported in the bottom of Table la, suggest that the absolute value of the error in the short own revenue forecasts has been falling by about 0.12 percentage points a year, and for long own revenue forecasts, by about 0.18 percentage polnts. These coefficlents are marginally significantly different from zero at conventional levels. The values of $\gamma_{1}$ for grants are also negative, but they are imprecisely estimated. One cannot reject the hypothesis of no improvement in the forecasts of federal grants.

Massachusetts. Budgetary data for Massachusetts are taken from the annual budget messages of January 1950 through January 1987. Like its New Jersey counterpart, the Massachusetts budget document includes actual revenue for the recently completed fiscal year as well as forecasts for the current and next fiscal year. As is also the case for New Jersey, there are many 
different sources of revenue, and we aggregated them into "own source" and "grants" categorles. However, changes in accounting procedures over time made it very difficult to construct a coherent time series for the sum of all own source revenues. Therefore, we focus instead on total tax revenues, which appear to have been consistently defined over the decades, and which accounted for over 90 percent of own source revenue in 1986.

Moreover, it was only in 1958 that the Massachusetts document began including federal grants. Hence, our regressions for grants are estimated using a shorter sample period than those for own revenues. For purposes of doing the strong tests of rationality, the same varlables are assumed to be in the information set as for New Jersey. 8

Summary statistics relating to the accuracy of the Massachusetts forecasts are presented in Table 1b. Comparing the summary statistics in Tables $1 a$ and $1 b$, we can see that own revenues have increased slightly faster in New Jersey than tax revenues in Massachusetts (.103 against .097 per year) and have been forecast with about the same accuracy. New Jersey is a bit better at the short forecast and Massachusetts at the long forecast. Like New Jersey, the estimates of $\gamma_{1}$ suggest that there has been no dramatic trend in the quality of the revenue forecasts, as measured by the absolute value of the forecast error. Federal grants have grown more slowly and been forecast more accurately in Massachusetts than New Jersey. (Reca 11, however, that the Massachusetts time serles on grants does not include the early 1950s.) The root mean squared error of the long grants forecast is 0.093 in Massachusetts as compared to 0.203 in New Jersey.

Maryland. Forecasted and actual values of state revenues in Maryland are taken from the annual budget messages of the governor and reports of the state comptroller for fiscal years 1946 through 1987. While short est imates 
of grants are avallable back to 1954, a coherent time series of long estimates of grants can only be constructed for fiscal years 1972 through 1987. As "own source" revenues, we aggregated al1 revenue sources whtch are categorized in Maryland as "Genera 1 Fund" revenues. This category makes up about $75 \%$ of non-grant evenues, and includes a 11 non-dedicated state funds such as receipts from the individual income tax, corporate income tax, and the retail sales and use tax. Time series for both short and long forecasts of own source revenues are avallable starting in fiscal year 1946. The varlables relating to the political environment are from Boyd [1987].

The Maryland summary statistics are presented in Table 1c. All sources of revenue grew at faster rates in Maryland than the ir counterparts in New Jersey and Massachusetts. (Reca11, however, that the time periods over which the averages are taken differ somewhat across the states as do the definitions of "own revenues.") With respect to forecasts of own source revenues, the qualitative picture is much the same as that for New Jersey and Massachusetts--on average, revenues are underforecast, and there has been some tendency for the absolute value of the forecast errors to fall over time.

As is a lso the case in New Jersey and Massachusetts, grants play an important role to state public finance. In 1987, the ratio of grant to non-grant revenues was about 24 percent; it has been as $h i g h$ as 31 percent. However, Table ic indicates that unlike New Jersey and Massachusetts, in Maryland predictions of grants are too optimistic on average. Moreover, using any method for measuring the errors, the grants forecasts are much worse than in New Jersey and Massachusetts. Closer investigation of the data indicated that these results are dominated by several years in the mid-1970s, when the forecast rate of growth of grants exceeded the actual by as much as 
86 percentage points. According to the budget officlals we consulted, those errors were largely due to unanticipated increases in the prices of petroleum products.

\section{Econometric Issues and Results}

\section{A. Econometric Issues}

As noted in section III, execution of the weak tests invoives estimating $R_{t}=\alpha_{0}+\alpha_{1} R_{t-f}^{e}+u_{t}$, and testing the joint hypothes is $\alpha_{0}=0$ and $\alpha_{1}=1$. Suppose that ordinary least squares estimation of this equation leads to errors that are serially correlated. This suggests that strong rationality will be rejected, because information that was available when the prediction was made (the previous forecast error) was not being taken into account. Nevertheless, weak rationality can still obtain. However, in the presence of autocorrelated errors, inferences based on the least squares errors may be incorrect. Moreover, standard "f $1 x$-ups" such as quasi-differencing will not work in this situation because there is no guarantee that the error term in perlod $t$ will be orthogonal to the lagged value of the right hand side variable. Newey and West [1987] have proposed a procedure for correcting the standard errors without quas1-differencing, and it is used whenever autocorrelation is diagnosed in the ordinary least squares results. 9

\section{B. Results: Weak Tests of Rationality}

New Jersey. The tests of weak rationality are presented in panel (a) of Table 2. Consider column (1) which shows the results for the short forecasts of own revenues. The ordinary least squares estimate of $\alpha_{0}$ is 0.0386 ; the standard error is 0.00833 . One can reject the hypothes is that $\alpha_{0}$ is zero. The estimate of $\alpha_{1}$ is 0.873 , with a standard error of 0.0625 . At 
conventional significance levels, the hypothes is that $\alpha_{1}=1$ is also rejected. Of course, whether the data are consistent with weak rationality depends on the outcome of the joint hypothes is that $\alpha_{0}=0$ and $\alpha_{1}=1$. The $p$-value for the approprlate ch1-square test is 0.00 . Thus, the data reject by a wide margin that the short forecasts of own revenue are weakly rational. It was already clear from Table la that New Jersey's short own revenue forecasts tend to be blased dowrward. The estimates of $\alpha_{0}$ and $\alpha_{1}$ in Table 2 indicate that there is no simple way to characterize the nature of the bias. That is, forecasters do not always underforecast by the same number of percentage points (because $\alpha_{1}$ is not zero); neither do they underforecast by a constant proportion of the correct forecast (because $\alpha_{0}$ is not zero). Hence, there does not appear to be a simple rule of thumb producing the discrepancy between actual and predicted forecasts of own revenues.

Column (2) shows the results for the short forecasts of grants. An examination of the coefficients one at a time seems promising for the null hypothes is of weak rationality-- $\alpha_{0}$ is on ly 1.3 times its standard error, and $\alpha_{1}$ is within one standard error of unity. This impression is confirmed by the joint test, which has a $p$-value of 0.408 . Thus, unlike own revenues, the short forecasts for grants are weakly rational. Although the grants forecasts are "worse" in the sense of having a lower $R^{2}$, they are unblased.

The results for the long forecasts of own revenues are shown in column (3). Like the short forecasts of own revenues, the data clearly reject the hypothes is of weak rationality. The situation for the long forecasts of grants in column (4) is somewhat more murky. The p-value for the joint hypothes is is 0.0156 , so one would reject the null hypothes is at a 5 percent level, but accept it at a 1 percent level.

Just as was true with the short forecasts, the $R^{2}$ of the long forecasts 
of grants is less than the $R^{2}$ for own revenues. Both long forecasts have lower $R^{2}$ 's than either of the short forecasts. Not surprisingly, the farther into the future one predicts, the more noise there is in the forecast.

Massachusetts. The weak tests of rationality for Massachusetts are presented in panel (b) of Table 2. In several important respects, the results are simflar to those for New Jersey. Weak rationality cannot be rejected for the short forecasts of grants; it is rejected decisively for long forecasts of revenues. Moreover, the $\mathrm{R}^{2}$ 's for the long forecasts in each category are smaller than those of the assoctated short forecasts. But there are several differences as we 11 . For short forecasts of own revenues, weak rationality is not decisively rejected; the p-value is 0.0291 , Indicating that at a one percent significance level one would accept the hypothes is. On the other hand, for long forecasts of grants, the Massachusetts data are clearly consistent with weak rationality, while for New Jersey, the outcome was more ambiguous.

Maryland. The weak tests of rationality are in panel (c) of Table 2. As was the case for Massachusetts, weak rationality for the short forecasts of own revenues is not decisively rejected; the p-value is 0.0101 , indicating that at a one percent significance level one would (barely) accept the hypothes is. For the long forecasts of own revenues, the results are identical to those of both New Jersey and Massachusetts--weak rationality is rejected. It appears, then, that the greater reliance on econometric forecasting methods in Maryland does not make much of a difference. One could argue that this inference is unfair, given that Maryland oniy began using econometrics for forecasting own revenues after 1973. We therefore estimated the equations separately for the before and after 1973 periods. Using standard F-tests, one cannot reject the joint hypothes is that $\alpha_{0}$ and $\alpha_{1}$ 
were the same during the two perlods. Specifically, for the short forecasts, the significance level of the test was 0.790 ; for the long forecasts, it was 0.248 .

We do not regard these results as "proof" that econometric forecasting methods are useless--it could be that Maryland implements these methods poorly, and/or that the results are ignored by political decision-makers, and/or that for some reason revenues have become intrinsically more difficult to forecast since 1973, so that in the absence of econometric methods, the results would have been worse. Sti11, on the bas is of these results, one would have to be cautious about urging states to fire their "old hands" and replace them with computers.

Turning now to the grants forecasts, we see that unlike New Jersey and Massachusetts, weak rationality is rejected. This finding is not altogether surprising given the discussion surrounding Table 1c. The series of gigantic over-predictions of grants in the mid-1970s makes it impossible that the forecasts as a whole would exhibit weak rationality.

\section{Results: Strong Tests of Rationality}

New Jersey. In light of the fact that the New Jersey data already rejected weak rationality for own revenues, we expect that strong rationality w111 also be rejected. Nevertheless, it is st111 of some interest to examine the coefficients on the various variables in the information set. This should indicate which information is not being properly assimilated into the forecasts. In contrast, on the basis of the weak tests, the grants equations are st111 in the game. For them, a test of the joint hypothes is that a 11 the coefficlents are zero is of considerable interest.

Table $3 a$ shows the results for the strong tests. As noted above, the 
information set includes economic variables from the calendar year preceding the budget message, except for income, which is lagged by a year. In interpreting the coefficients, note that a negative coefficient means that an increase in the associated variable makes the forecast more optimistic, ceteris paribus. Consider, for example, the column (1) results for the short forecasts of own revenues. On the basis of $t$-tests conducted at conventional significance levels, the variables that stand out as significant are $R_{t-f-1}$, REPUB, FIRSTYR, and ELECTYR. Except for REPUB, they all have negative coefficlents. Thus, larger percent increases in lagged own revenues are assoclated with more optimistic revenue forecasts. Forecasts made during election years tend to be more optimistic than average, as are those made during the first year of an administration. Republican administrations tend to be pessimistic about revenue growth. The qualitative story with respect to these coefficients is about the same for the long own revenue forecasts in column (3). Here, however, none of them is statistically significant.

We turn now to the grants forecasts. Given that both the short and long forecasts passed the test for weak rationality (at a 1 percent significance leve1), the key question is whether they pass the strong tests as we11. For the short forecasts (column (2)), the p-value for a joint test of the hypothes is that a 11 the coefficients are zero is 0.0620 ; for the long forecasts (column (4)), the $p$-value is 0.0821 . Thus, in netther case can we reject the hypothes is that a 11 the regression coefficients are zero. All the information is assimilated into New Jersey's grants forecasts, 1.e., they are strongly ratfonal.

Massachusetts. The strong tests of rationality for Massachusetts are reported in Table 3b. Consider first the short forecasts of own revenues. Except for the POP and CPI vartables, the signs and magnitudes are quite 
simflar to those for New Jersey. Thus, for example, increases in past revenues lead to more optimistic forecasts, as do being in the first year of an administration and being in an election year. Like their New Jersey counterparts, the Republican governors of Massachusetts tend to be more pessimistic about revenues than the Democrats (compare the coefficient on REPUB of 0.0183 to 0.0205 from column (1) of Table $3 a$ ). Of course, one should not make too much of these simflarities, given that on a one-by-one basis, the coefficients in column (1) are insignificantly different from zero. Similarly, the column (3) results for the long forecasts of own revenues do not contain any signiffcant variables.

With respect to the results for grants in columns (2) and (4), the key result is that one cannot reject the hypothes is that all the coefficients are zero; the $p$-value for the short forecasts is 0.427 and for the long forecasts, 0.229. It appears, then, that even more decisively than in the case of New Jersey, forecasters incorporate all of the relevant information Into the ir forecasts of grants.

Maryland. The strong tests of rationality for Maryland are reported in Table 3c. As was the case for New Jersey and Massachusetts, strong rationality is rejected for forecasts of own source revenues. However, on a coeffictent by coefficient basis, many of the results are different. In particular, the signs of the "political" variables are reversed. While one should not make too much of this result due to the fact that the individual coeffictents are imprecisely estimated, it is perhaps worth noting that unl1ke New Jersey and Massachusetts, during our sample perlod Maryland was pretty much a one-party state. The Democrats controlled the governorship for all but two years. (The one Republican was Spiro T. Agnew.) This political environment differs considerably from that in New Jersey and Maryland; we 
confecture that this difference might affect political incentives to over-or underest imate revenues.

Columns (2) and (4) of Table $3 c$ indicate that forecasts of grants in Maryland are not strongly rational. Given the results in Tables $1 \mathrm{C}$ and pane 1 (c) of Table 2, it is no surprise to find that forecasts of grants in Maryland do not incorporate all of the relevant information.

\section{v. Conclusion}

This paper has suggested a framework for examining whether state revenue forecasts are formed rationally, and used this framework to analyze budget data from New Jersey, Massachusetts, and Maryland. The states are remarkably similar in several ways: a) on average the forecasts of the growth of own revenues have fallen short of actual growth; b) there has been some tendency for the forecasts of own revenues to improve over time, but the improvement is generally not statistically significant; and $c$ ) forecasts of own revenues fail to incorporate all the information avallable to the forecasters.

On the other hand, we have also found some differences among the three states. The most important of these concern the forecasts for federal grant receipts. In New Jersey and Massachusetts, forecasts of grants are weak ly and strongly rational; in Maryland they are neither. The results for New Jersey and Massachusetts seem more intuitive. Federal grants depend partially on expenditures from state funds. Their underestimation will neither restrain legisiative spending in a way that might be desired by the executtve, nor provide the executive with "unexpected" surpluses out of which to fund favored programs. 10 As we noted earlier, the time series on grants forecasts for Maryland is dominated by several large outliers in the mid-1970s. Of course, it is illegitimate to discard outliers from a time 
serles, and we have not done so. St111, our guess is that if the grants forecasts of other states are analyzed, they will tend to be more like those of New Jersey and Massachusetts than those of Maryland.11

We also found that Maryland's more extens ive use of econometric methods does not seem to have produced results much different than those of New Jersey and Massachusetts. However, data on more states are required to test carefully whether differences in state budgetary methods and institutions affect the quality of revenue forecasts. 
Table 1a*

Summary Statistics: New Jersey

(i)

Short Horizon

Own

Revenues

1) $R_{t}$

2) $\left(R_{t}-R_{t-f}^{e}\right)$

3) $\mid R_{t}-R_{t-f}^{e}$

4) R.M.S.E.

Trend in $\left|R_{t}-R_{t-f}^{e}\right|$ :

$$
0.103
$$

$(0.0934)$
(2)

Grants
(3)

Long Hor izon

Own

Revenues

Grants

0.141
$(0.237)$

0.227

$(0.141)$

0.287

$(0.317)$

$\begin{array}{rcr}0.0292 & 0.0219 & 0.0697 \\ (0.0342) & (0.109) & (0.0805) \\ 0.0316 & 0.0863 & 0.0776 \\ (0.0318) & (0.0696) & (0.0728)\end{array}$

0.110

0.106
$(0.0836$

$(0.188)$

0.147

(0.142)

0.203 ro

$0.0647^{\star \star}$

$(0.0208)$

$\gamma_{1}$

$-0.00121 * \star$

$(0.000665)$

$0.0932 \quad 0.126$

$(0.0303) \quad(0.0311)$

0.211

$(0.0620)$

$-0.00230$

$-0.000248 \quad-0.00176$

$(0.00100) \quad(0.00105)$

*Notation: $R_{t}=$ actual percent change in nominal revenues

$R_{t-f}^{e}=$ forecast of $R_{t}$ made $f$ periods ago

$\left(R_{t}-R_{t-f}^{e}\right)=$ forecast error

$\left|R_{t}-R_{t-f}^{e}\right|=$ absolute value of forecast error

R.M.S.E. = root mean squared error of forecast

For the "long horizon," $R$ : and $R_{t-f}^{e}$ are calculated over a two year period; the numbers are not annualized.

Numbers in parentheses are standard deviations (for means), or standard errors (for regression coefficients).

**Estimates obtained after quasi-differencing to correct for autocorrelation. (According to the Durbin-Watson statistic, this was not required for the other equations.) 


\section{Table $1 b^{\star}$}

Summary Statistics: Massachusetts

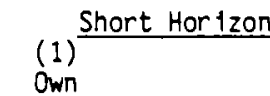

Revenues

0.0975

$(0.0772)$
(2)

Grants

1) $R_{t}$

2) $\left(R_{t}-R_{t-f}^{e}\right)$

$$
0.0216
$$

(0.0485)

0.0191
$(0.0696)$

0.0884

$(0.107)$

0.186
$(0.100)$

0.172

$(0.122)$

(3) (4)

Revenues

Grants

3) $\left|R_{t}-R_{t-f}^{e}\right|$

0.0302

(0.0435)

0.0494
$(0.0518)$

0.0366

$(0.0873)$

0.0369

$(0.0867)$

4) R.M.S.E.

0.0525

0.0709

0.0666

$(0.0665)$

0.0746

$(0.0560)$

Trend in $\left|R_{t}-R_{t-f}^{e}\right|$

Yo

0.0357

(0.0152)

0.0139

(0.345)

0.102

(0.0222)

0.0979

(0.0379)

$\gamma_{1}$

$-0.000304$

(0.000738)

$-0.00200$

$(0.00107)$

*See notes to Table $1 b$. 
Table $1 c^{\star}$

Summary Stat1stics: Maryland

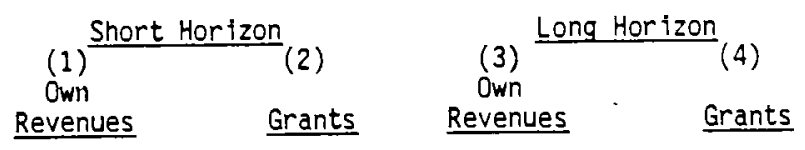
1) $R_{t}$
0.132
0.153
0.281
0.330
$(0.110)$
$(0.133)$
$(0.175)$
$(0.210)$
2) $\left(R_{t}-R_{t-f}^{e}\right)$
0.0286
$(0.0507)$
$-0.116$
$(0.251)$
0.112
$(0.137)$
$-0.293$
0.0318
0.176
$(0.213)$
0.113
$(0.135)$
(0.310)
3) $I R_{t}-R_{t-f^{\prime}}^{e}$
$(0.0487)$
0.273
0.175
0.308
(0.294)
4) R.M.S.E.
0.0580
0.421

Trend in $\left|R_{t}-R_{t-f}^{e}\right|$ :

$\begin{array}{ccccc}\text { ro } & 0.0735 & 0.0266^{\star \star} & 0.254 & 1.888^{\star \star} \\ & (0.0174) & (0.135) & (0.0492) & (0.557) \\ \text { Y1 } & -0.00151 & 0.00465^{\star \star} & -0.00502 & -0.0390 \star \star \\ & (0.000580) & (0.00533) & (0.00162) & (0.0128)\end{array}$

* See notes to Table la.

**Estimates obtained after quasi-differencing to correct for autocorrelation. (According to the Durbin-Watson statistic, this was not required for the other equations.) 
Table 2

Weak Tests of Rational1ty*

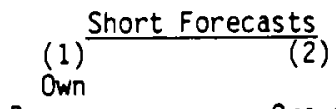

Revenues
Grants

(a) New Jersey $a_{0}$

$a_{1}$

D-W

$\mathrm{R}^{2}$

$p\left(\alpha_{0}=0, \alpha_{1}=1\right)$

$\alpha_{0}$

$\alpha_{1}$

$D-W$

$\mathrm{R}^{2}$

$P\left(\alpha_{0}=0, \alpha_{1}=1\right)$
0.0386

$(0.00833)$

0.873

$(0.0625)$

$\begin{array}{cc}0.0272 & 0.105 \\ (0.0202) & (0.0169)\end{array}$

$$
0.956
$$$$
\text { (0.0813) }
$$

0.772
$(0.0764)$

1.81

0.74

0.79

0.408

0.00

0.0156

(b) Massachusetts

$\begin{array}{lcccc}\alpha_{0} & 0.0305 & -0.0106 & 0.0916 & 0.0626 \\ \alpha_{1} & (0.0123) & (0.0225) & (0.0214) & (0.0398) \\ 0.883 & 0.921 & 0.633 & 0.810 \\ (0.121) & (0.162) & (0.124) & (0.136) \\ D-W & 2.45 & 2.45 & 1.33 & 1.28 \\ R^{2} & 0.62 & 0.58 & 0.36 & 0.53 \\ P\left(\alpha_{0}=0, \alpha_{1}=1\right) & 0.0291 & 0.373 & 0.0009 & 0.232\end{array}$


Table 2 (continued)

(c) Maryland

$\begin{array}{lcccc}\alpha_{0} & 0.0259 & 0.0890 & 0.129 & 0.0723 \\ & (0.0116) & (0.0273) & (0.0324) & (0.0820) \\ \alpha_{1} & 1.026 & 0.239 & 0.900 & 0.415 \\ & (0.112) & (0.0690) & (0.109) & (0.109) \\ D-W & 1.50 & 2.26 & 1.47 & 1.87 \\ R^{2} & 0.79 & 0.28 & 0.39 & 0.51 \\ P\left(a_{0}=0, a_{1}=1\right) & 0.0101 & 0.00 & 0.00 & 0.00\end{array}$

*Numbers in parentheses are standard errors. In cases where the Durbin-Watson statistic rejects the null hypotehs is of no autocorrelation, standard errors are computed using Newey and West's [1987] correction for autocorrelation. 
Table 3a

Strong Tests of Rationality: New Jersey*

(1) $\frac{\text { Short Forecasts }}{(2)}$

Own

Revenues

0.0701

$(0.0174)$

INCt-2

POP $_{t-1}$

$C P I_{t-1}$

EMP $t-1$

$R_{t-f-1}$

REPUB

FIRSTYR

ELECTYR

GOVAGR

D-W

$R^{2}$

p(all coeffictents

= zero)

1.34

$(0.467)$

0.0320

(0.116)

0.199

(0.163)

$-0.138$

0.0205
$(0.0107)$

$-0.0256$

$(0.00787)$

$-1.44$

(0.0116)

0.00509

$(0.00732)$

0.959

0.45

0.00
Grants

$-0.0969$

$(0.0696)$

(0.782)

\subsection{9}

(1.98)

$(0.0619)$

(0.694)

$-0.398$

$(0.561)$

$-0.0350$

(0.0699)

$-0.0532$

(0.0355)

0.00281

$(0.0505)$

0.0315

$(0.0404)$

0.0921

$(0.0415)$

2.22

1.99

2.27

0.40

0.27

0.30

0.0620

0.00494
(4)

Grants
(3)

Revenues

0.169

0.316

$(0.708)$

$-1.52$

(1.70)

6.69

(4.56)

0.00143

(1.56)

0.386

(1.06)

0.181

(0.132)

$-0.0363$

$(0.0726)$

0.0749

(0.0959)

$-0.0402$

$(0.0810)$

0.0635

(0.0792)

* Numbers in parentheses are standard errors. In cases where the DurbinWatson statistic rejects the null hypothes is of no autocorrelation, standard errors are computed using Newey and West's [1987] correction for autocorre lation. 
Strong Tests of Rationality: Massachusetts*

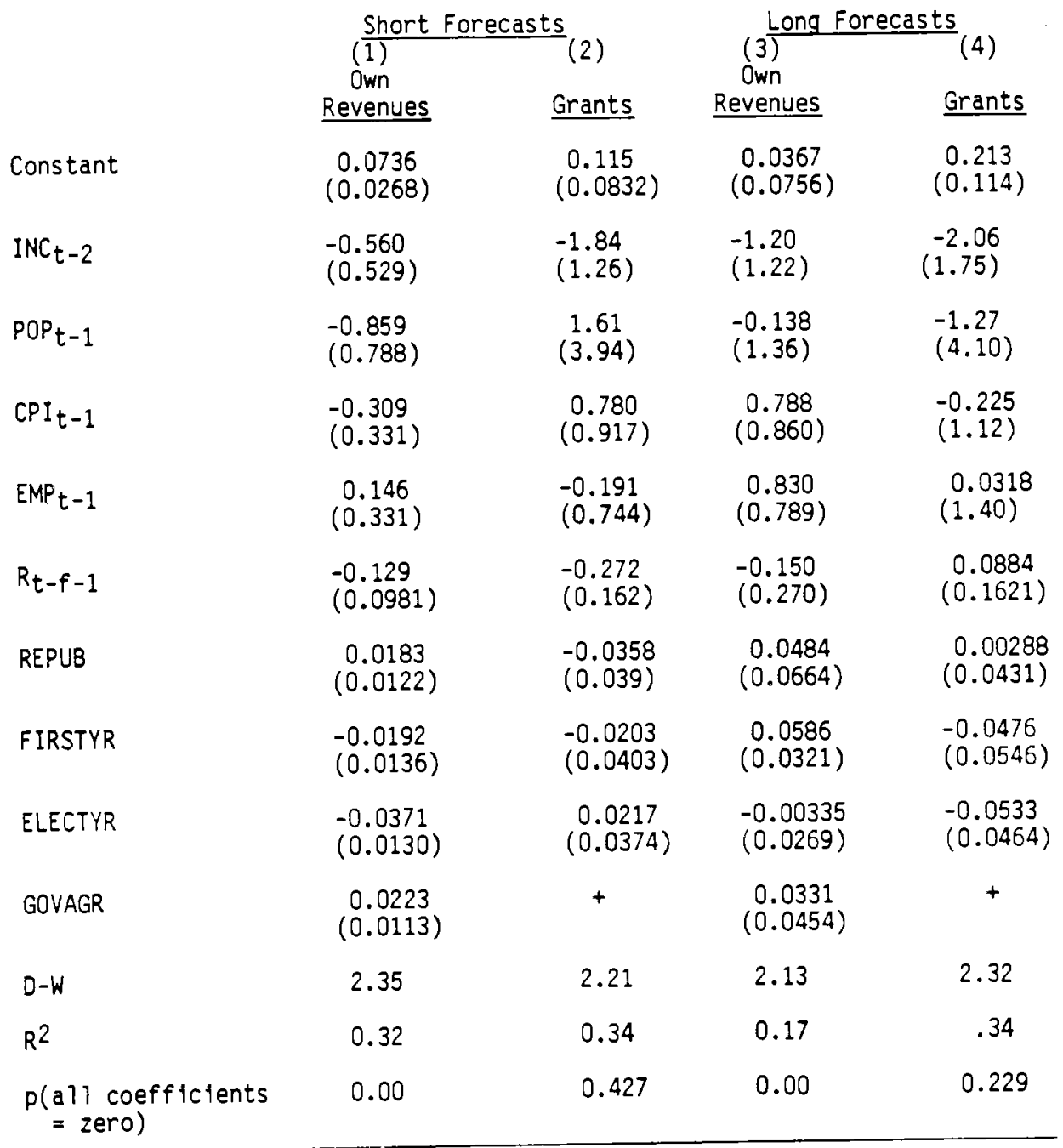

* Numbers in parentheses are standard errors. In cases where the DurbinWatson statistic rejects the null hypothes is of no autocorrelation, standard errors are computed using Newey and West's [1987] correction for autocorrelation.

+The time period used to estimate the grants equations was 1958-1987; during this period GOVAGR was perfectly colitinear with other right hand side variables, and therefore had to be omitted. This problem did not arise in the longer period (1950-1987) used to estimate the own revenue equations. 
Table 3c

Strong Tests of Rationality: Maryland*

\begin{tabular}{|c|c|c|c|c|}
\hline & $\begin{array}{r}\text { Short F } \\
\text { (1) } \\
\text { Own } \\
\text { Revenues }\end{array}$ & $\begin{array}{l}\text { sts } \\
\text { Grants }\end{array}$ & $\begin{array}{c}\text { (3) } \\
\text { Own } \\
\text { Revenues } \\
\end{array}$ & $\begin{array}{l}\text { (4) } \\
\text { Grants }\end{array}$ \\
\hline Constant & $\begin{array}{l}-0.00511 \\
(0.00533)\end{array}$ & $\begin{array}{l}-0.0199 \\
(0.140)\end{array}$ & $\begin{array}{c}0.0959 \\
(0.0637)\end{array}$ & $\begin{array}{l}-0.199 \\
(0.428)\end{array}$ \\
\hline INC $t-2$ & $\begin{array}{c}0.0524 \\
(0.0722)\end{array}$ & $\begin{array}{c}0.284 \\
(0.999)\end{array}$ & $\begin{array}{c}0.520 \\
(0.534)\end{array}$ & $\begin{array}{c}2.67 \\
(3.61)\end{array}$ \\
\hline$P_{t-1}$ & $\begin{array}{c}0.825 \\
(0.219)\end{array}$ & $\begin{array}{l}4.15 \\
(3.17)\end{array}$ & $\begin{array}{l}-1.38 \\
(1.71)\end{array}$ & $\begin{array}{l}-8.18 \\
(7.40)\end{array}$ \\
\hline$C P I_{t-1}$ & $\begin{array}{l}0.127 \\
(0.0895)\end{array}$ & $\begin{array}{l}-2.73 \\
(1.60)\end{array}$ & $\begin{array}{l}-1.04 \\
(0.743)\end{array}$ & $\begin{array}{l}-1.46 \\
(2.84)\end{array}$ \\
\hline$E M P_{t-1}$ & $\begin{array}{l}-0.0740 \\
(0.125)\end{array}$ & $\begin{array}{l}-2.060 \\
(0.686)\end{array}$ & $\begin{array}{l}-1.94 \\
(0.771)\end{array}$ & $\begin{array}{l}-2.32 \\
(2.98)\end{array}$ \\
\hline$R_{t-f-1}$ & $\begin{array}{l}-0.00120 \\
(0.0137)\end{array}$ & $\begin{array}{l}-0.175 \\
(0.173)\end{array}$ & $\begin{array}{l}-0.0777 \\
(0.116)\end{array}$ & $\begin{array}{l}-0.245 \\
(0.305)\end{array}$ \\
\hline REPUB & $\begin{array}{l}-0.0116 \\
(0.00986)\end{array}$ & $\begin{array}{l}0.102 \\
(0.0414)\end{array}$ & $\begin{array}{c}0.0947 \\
(0.0419)\end{array}$ & + \\
\hline FIRSTYR & $\begin{array}{l}0.0219 \\
(0.00711)\end{array}$ & $\begin{array}{c}0.0596 \\
(0.0516)\end{array}$ & $\begin{array}{l}0.154 \\
(0.0526)\end{array}$ & $\begin{array}{l}-0.0662 \\
(0.0903)\end{array}$ \\
\hline ELECTYR & $\begin{array}{r}0.000818 \\
(0.00696)\end{array}$ & $\begin{array}{l}-0.0454 \\
(0.0477)\end{array}$ & $\begin{array}{c}0.0464 \\
(0.0388)\end{array}$ & $\begin{array}{l}-0.112 \\
(0.170)\end{array}$ \\
\hline$D-W$ & 1.04 & 0.85 & 2.23 & 1.30 \\
\hline$R^{2}$ & 0.32 & 0.37 & 0.43 & 0.16 \\
\hline $\begin{array}{l}p(a 11 \text { coefficients } \\
=\text { zero })\end{array}$ & 0.0 & 0.0 & 0.0002 & 0.0 \\
\hline
\end{tabular}

*Numbers in parentheses are standard errors. In cases where the Durbin-Watson statistic refects the null hypothes is of no autocorrelation, standard errors are computed using Newey and West's [1987] correction for autocorrelation. Also, the variable GOVAGR is perfectly collinear with other right hand side varlables throughout all the sample perlods considered here, and is therefore omitted.

+The time perlod used to estimate the equations for long forecasts of grant revenues was 1972-1987; during this perlod there were no Republican Governors in Maryland, and therefore the varlable REPUB was omitted. This problem did not arise in the longer perlods used to estimate the other equations. 


\section{Footnotes}

1. See, for example, Litterman and Supe 1 [1983]. Klay [1983] and Hyde and Jarocki [1983] discuss the various institutional arrangements for making revenue forecasts, summarize the techniques that have been used, and provide brief histories of state revenue forecasting.

2. For some examples, see Bernheim [1987] on expected social security benefits, Zarnowitz [1985] on expected business conditions such as GNP and the inflation rate, Leonard [1982] on businesses' wage expectations, and Mank iw and Shapiro [1986] on the GNP predictions made by the Bureau of Economic Analysis. Love11 [1986] summarizes a number of other studies.

3. The analysis can just as well be conducted in terms of levels as percent changes; we follow Zarnowitz [1985] and others in using percent changes.

4. New York Times, May 26, 1988, p. B1.

5. Before 1973, the message was presented in mid-February.

6. An important example is the state income tax, which has only been in existence since the 1970 s.

7. Data sources for New Jersey are as follows: Employment: Bureau of Labor Statistics, Statistical Abstract of the United States, various issues; Political Affiliations (for both governor and state legislators): Counc $i$ of State Governments, Book of the States, various issues; CPI: Economtc Report of the President 1987, Table B-57; Population and Personal

Income: Bureau of Economic Analys is, State Personal Income: 1929-82, U.S. Government Printing Office, Washington, OC 1984, pp. 79-82, 
and updated with various issues of the Statistical Abstract of the United States.

8. INC, POP, CPI and EMP are from the same sources as New Jersey. REPUB, FIRSTYR, GOVAGR and ELECTYR are from Dalton and Wirkkala [1984].

9. Brown and Maltal [1981] stress that for mult1-perlod ahead forecasts, the error terms may be moving averages. The Newey-West procedure produces consistent standard errors in the presence of such an error structure.

10. We are grateful to a referee for pointing out this fact to us.

11. Another possible reason for the poor quality of Maryland's grants forecasts is that they are not integrated with the rest of the budget document. That is, the "bottom line" that indicates whether the budget is in balance is not affected by the forecast of grants. 


\section{REFERENCES}

Bernheim, B. Douglas, "The Timing of Retirement: A Comparison of Expectations and Realizations," National Bureau of Economic Research, Working Paper No. 2291, June 1987.

Boyd, Las 10, Maryland Government and Politics, Centreville, Maryland: Tidewater, 1987.

Brown, Byron W. and Shlomo Maital, "What Do Economists Know? An Empirical Study of Experts' Expectations," Econometrica 49, March 1981, 491-504. Dalton, Cornelius and John Wirkkala, Leading the Way--A History of the Massachusetts Genera 1 Court 1929-1980, Boston: Massachusetts Genera 1 Court, 1984.

Giovinazzo, Vincent J., State Revenue Estimating--An Econometric Approach Applfed to Conditions in New Jersey, Ph.D. Dissertation, School of Business Administration, New York University, 1971.

Hyde, Albert $C$. and William R. Jarockf, "Revenue and Expenditure Forecasting:

Some Comparative Trends," in R. P. Golemblewski and J. Rabin (eds.), Public Budgeting and Finance: Behavioral, Theoretical, and Technical

Perspectives, 3rd edition, New York: Marce 1 Dekker, 1983.

Inman, Robert P., "The Fiscal Performance of Local Governments: An

Interpretive Review," in P. Mieszkowski and M. Straszheim (eds.), Current Issues in Urban Economics, Baltimore: John Hopkins, 1979, $270-321$.

Klay, William E., "Revenue Forecasting: An Administrative Perspective,"

in J. Rabin and T. D. Lynch (eds.), Handbook of Public Budgeting and Financial Management, New York: Marcel Dekker, 1983. 
Leonard, Jonathan F., "Wage Expectations in the Labor Market: Survey Evidence on Rationality," Review of Economics and Statistics, February $1982,157-61$.

Litterman, Robert B. and Thomas M. Supe 1, "Using Vector Autoregressions to Measure the Uncertainty of Minnesota's Revenue Forecasts,"

Federal Reserve Bank of Minneapolts Quarterly Review, Spring 1983, 10-22. Love11, Michae1 C., "Tests of the Rational Expectations Hypothes is," American Economic Review 76, March 1986, 110-124.

Mankiw, N. Gregory, and Matthew D. Shapiro, "News or Noise: An Analysis of GNP Revisions," Survey of Current Business, May 1986, 20-25. Newey, Whitney $K$. and Kenneth D. West, "A Simple, Positive Semi-Definite, Heteroscedasticity and Autocorrelation Consistent Covariance Matrix," Econometrica 55, May 1987, 703-708.

U. S. Bureau of the Census, Statistical Abstract of the United States: 1988 (108th edition). Washington, D.C.: U.S. Government Printing Office, 1987.

Zarnowitz, Victor, "Rational Expectations and Macroeconomic Forecasts," Journal of Bus iness and Economic Statistics, October 1985, 293-311. 